\title{
Resurrection of Porites hawaiiensis Vaughan, 1907; a Hawaiian coral obscured by small size, cryptic habitat, and confused taxonomy
}

\author{
ZAC H. FORSMAN ${ }^{1,3}$, JONATHAN A. MARTINEZ ${ }^{1}$, JIM E. MARAGOS ${ }^{2} \&$ ROBERT J. TOONEN ${ }^{1}$ \\ ${ }^{1}$ Kewalo Marine Laboratory, University of Hawaii Honolulu, HI 96713. E-mail: ${ }^{3}$ zac@ hawaii.edu \\ ${ }^{2}$ U.S. Fish and Wildlife Service, Honolulu HI, 96850
}

The purpose of this note is to propose recognition of Porites hawaiiensis Vaughan, 1907, (Figure 1A-D) a species currently regarded as a junior synonym of Porites rus (Forskål 1775), as a valid species, based on molecular and morphological characteristics. Vaughan (1907 p. 217, pl 91 figs 2, 2a) described Porites (Synaraea) hawaiiensis from a specimen collected from Kalihi Harbor on the island of O'ahu, Hawai' $\mathrm{i}$ (Figure $1 \mathrm{C}$ ). Porites (Synarea) hawaiiensis was also reported from the Marshall Islands by Wells (1954 p. 455, pl 170 figs 6,7). Porites hawaiiensis was subsequently thought to be a junior synonym of Porites (Synaraea) convexa Verrill, 1864, due to the small calices that are characteristic of the subgenus Synaraea (Maragos 1977). Later both species were made synonyms of $P$. (Synaraea) rus, Forskål 1775 (Veron \& Pichon 1982; Cairns 1991). Vaughan, 1907 described the calices of P. hawaiiensis as "densely spinulose" with "coenchyma" equaling, or exceeding the $0.5 \mathrm{~mm}$ diameter of the calices, and a pitted star shaped space between the pali (Figure 1C,D). In the absence of living specimens, the Vaughan, 1907 type specimen was difficult to distinguish from newly settled $P$. rus colonies, but upon closer examination in the field, Maragos et al. (2004) recognized small coral colonies that appeared to match the description of $P$. hawaiiensis. This species can readily be distinguished from Porites rus and other Porites by very small colony size $(<10 \mathrm{~cm})$, mottled yellow and green-brown coloration, encrusting form, and thicket of spiny denticles between distantly spaced corallites (Figure 1A-D). Genetic data from Forsman et al. 2009 confirmed that this small 'patch coral' is distinct from P. rus $(\mathrm{n}=3$ of each species; uncorrected pairwise distance; $\mathrm{mtCOI}=0.5 \% \pm 0.2 \mathrm{SE} ; \mathrm{mtCR}=0.7 \%$, and nuclear ITS $=14.2 \% \pm 1.3 \mathrm{SE}$ ), and is also distinct from all other Hawaiian congeners. The genetic data further indicated that 'Synaraea' was surprisingly closely related to other Poritids and may not warrant sub-genus status (Forsman et al. 2009). Fenner (2005) referred to this same small 'patch coral' as Porites cf. bernardi, however; P. bernardi Vaughan, 1907 type specimens were coralliths (Figure 1E) with calices similar in size to those of most other Porites (Figure 1 F). The geographic range of Porites hawaiiensis is unknown, although it is abundant throughout the Northwest and Main Hawaiian Islands, and has been reported at depths from 1 to $55 \mathrm{~m}$ (30 fathoms) in the Marshall Islands (Wells 1954). This species can be easily overlooked; it tends to grow in cryptic habitats (cracks, crevices, and interstitial spaces), and at first glance, the small patches of colonies $(0.5-10 \mathrm{~cm})$ can be confused with crustose coralline algae, or new recruits of other Porites species. This species is remarkable because of its small adult colony size; a curious life history characteristic since many Porites in the Pacific can be among the largest and longest-lived scleractinain corals (Brown et al. 2009). We propose that this small 'patch coral' is a distinct species, and that $P$. hawaiiensis is the most appropriate name.

\section{Acknowledgments}

We thank Lu Eldredge and Steve Coles for providing access to Bishop Museum specimens, and Steve Cairns and Tim Coffer from the Smithsonian Institution for supplying photographs of type specimens. We thank Carden Wallace, Doug Fenner, and an anonymous reviewer for comments that improved the manuscript. ZHF was supported by a fellowship from NOAA National Marine Sanctuaries Partnership MOA\#2005-008/66882. This is HIMB contribution \#1402 and SOEST \#8008. 

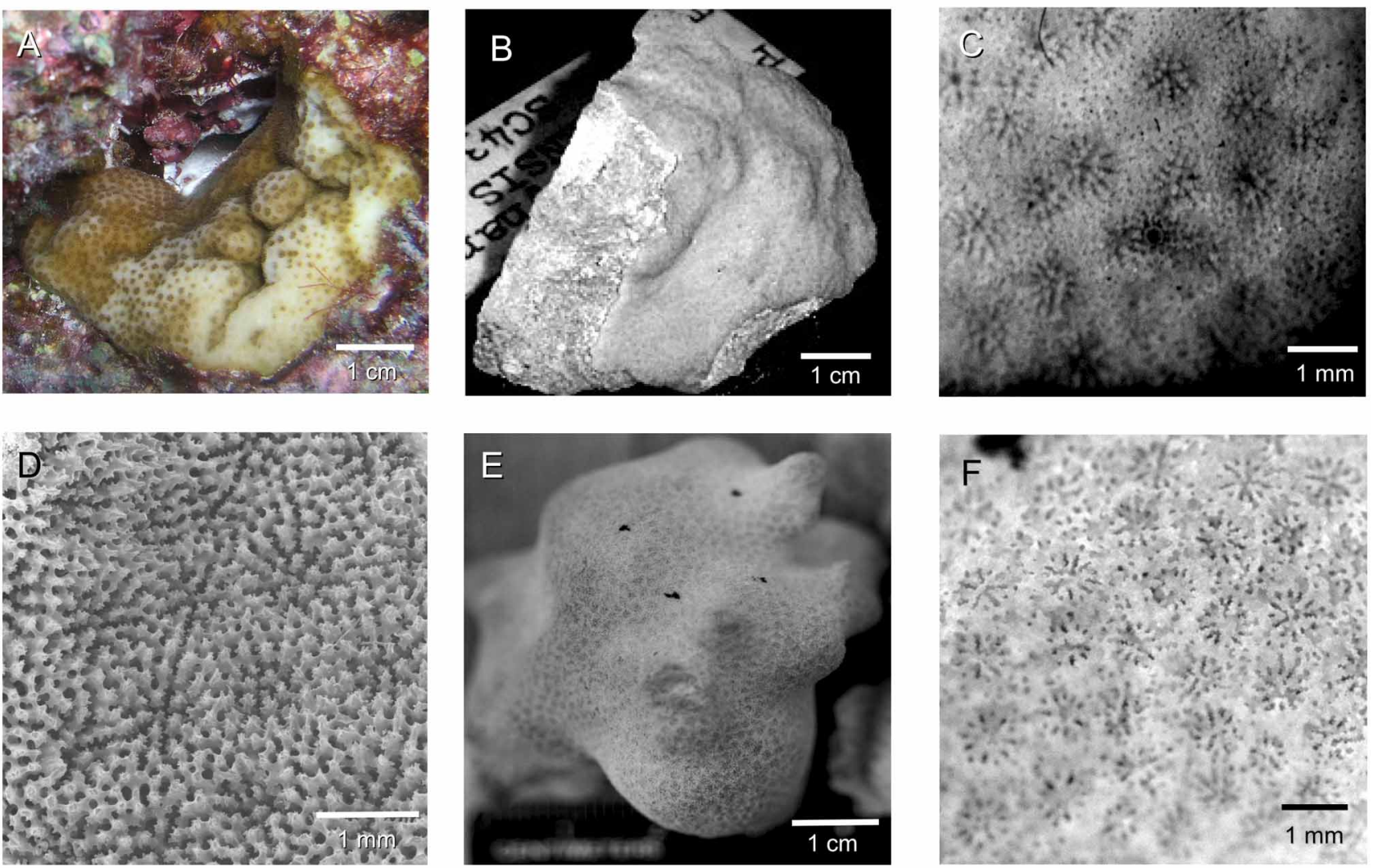

FIGURE 1. (A) P. hawaiiensis colony photographed in situ at La Perouse Bay Maui; (B) P. hawaiiensis topotype collected from Kalihi harbor by Duerden 1904 (Bishop Museum SC439); (C) Holotype of P. hawaiiensis Vaughan 1907 (United States National Museum at the Smithsonian Institution USNM21624); (D) SEM image of 'patch coral' sample \# HM54 from Forsman et al. 2009; (E) Cotype of P. bernardi Vaughan 1907 (United States National Museum at the Smithsonian Institution, USNM20820); (F) Close up of a cotype of P. bernardi (USNM20820).

\section{References}

Cairns, S.V. (1991) Catalogue of the type specimens of stony corals (Milleporidae, Stylasteridae, Scleractinia) in the National Museum of Natural History, Snithsonian Institution. Smithsonian Contributions to Zoology Number, 514, 59 pages.

Brown, D.P., Basch, L., Barshis, D., Forsman, Z.H., Fenner, D. \& Goldberg, J. (2009) American Samoa's island of giants: massive Porites colonies at Ta'u island. Coral Reefs, 28(3), 735-735.

Fenner, D. (2005) Corals of Hawaii. Mutual Publishing, Honolulu, 143 pp.

Forsman, Z.H., Barshis, D.J., Hunter, C.L. \& Toonen, R.J. (2009) Shape-shifting corals: molecular markers show morphology is evolutionarily plastic in Porites. BMC evolutionary biology, 2009, 9-45.

Forskål, P. (1775) Descriptiones Animalium, Avium, Amphibiorum, Piscium, Insectorum, Vermium que intinere orientali observavit Petrus Forskål. IV Corallia. Hauniae. 131-9.

Maragos, J.E. (1977) Order Scleractinia: Stony Corals. In: Devaney DM, Eldredge LG (eds) Reef and shore fauna of Hawaii, Bernice P. Bishop Museum Special Publication 64 (1): Protozoa through Ctenophora. Bishop Museum Press, Honolulu, p 158-241.

Maragos, J.E., Potts, D.C., Aeby, G., Gulko, D., Kenyon, J., Siciliano, D. \& Van Ravenswaay, D. (2004) 2000-2002 Rapid Ecological Assessment of Corals (Anthozoa) on Shallow Reefs of the Northwestern Hawaiian Islands. Part 1: Species and Distribution. Pacific Science, 58, 211-230.

Vaughan, T.W. (1907) Recent Madreporaria of the Hawaiian Islands and Laysan. Smithsonian Institution Unites States National Museum Bulletin, 59, 1-427.

Veron, J.E.N. \& Pichon, M. (1982) Scleractinia of Eastern Australia part IV Family Poritidae. Australian Institute of Marine Science monograph Series Volume 5. ANU Press, Canberra 159 pages.

Wells, J.W. (1954) Recent Corals of the Marshall Islands; Bikini and Nerby Atolls, Part 2 Oceanography (Biologic). Geological Survey Professional Paper 260-I. 